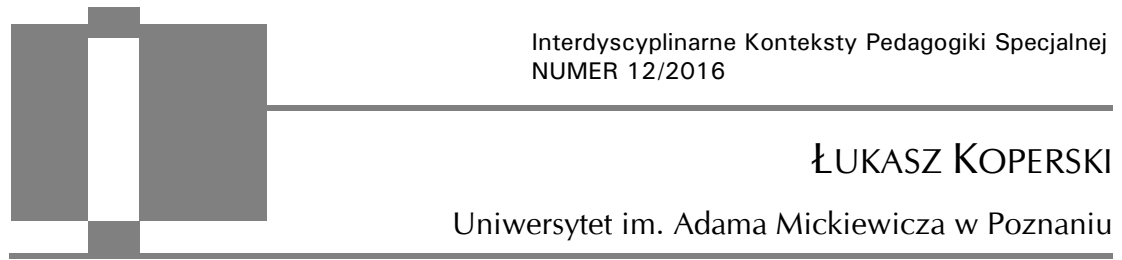

\title{
Znaczenie ruchu rodziców w procesie emancypacji osób niepełnosprawnych intelektualnie
}

\begin{abstract}
Koperski, Znaczenie ruchu rodziców w procesie emancypacji osób niepetnosprawnych intelektualnie [The importance of parents movement in the process of emancipation people with intellectual disabilities]. Interdyscyplinarne Konteksty Pedagogiki Specjalnej, nr 12, Poznań 2016. Pp. 165-184. Adam Mickiewicz University Press. ISSN 2300-391X
\end{abstract}

This article consists of three parts. The first made the characteristics of paradigm shifts in the perception of intellectual disability - from the medical model to the social and political and disability in terms of emancipation. The second part is dedicated to the rear movement of parents of persons with disabilities in a sociological theory of social movements and contemporary understanding of new forms of community. The third section presents the most important stages of development of the movement of parents of persons with disabilities in Poland since the 60 s to today, indicating the author's classification functions that they perform in the context of emancipation. The author at the beginning of the article poses the question of the role of parents in motion the creation of conditions for the emancipation of people with intellectual disabilities. At the same time it indicates that the movement of the parents may contribute to the emancipation of people with disabilities, by presenting them as autonomous individuals who deserve equal treatment, to support their autonomy and strengthening the sense of agency. Initiatives taken by the parents, or established with their participation entities, they tend to emphasize the role of socio-professional people with intellectual disabilities. The change at the same time is the media image of the same disabilities as people with talents, skills, resources or social skills at a high level. On the other hand, the movement of the parents may also contribute to the limitations of the emancipation of people with 
intellectual disabilities. The emphasis on the social question could result in the presentation and reception with disabilities as dependent, in need of constant care a consequence as a category helpless in life and socially. Indication of the emancipation of people with disabilities through active participation of parents in the public discourse enables better draw public attention to disability, which may contribute to the better understanding.

Key words: intellectual disability, movement of parents, social support

Rodzice działający w Stowarzyszeniu to oczywiście niezwykle różnorodna grupa, ale wszyscy, bez względu na wiek, płeć czy wykształcenie, budzą mój ogromny szacunek. Przede wszystkim dlatego, że znaleźli w sobie taką siłę i odkryli takie możliwości, które pozwoliły przezwyciężyć własny problem i „zagospodarować" go na użytek innych osób, które nie potrafią tego robić.

Barbara Ewa Abramowska, Prezes Polskiego Stowarzyszenia na Rzecz Osób z Upośledzeniem Umysłowym ${ }^{1}$

\section{Wstęp}

Powyższy fragment został zawarty $\mathrm{w}$ drugim wydaniu książki zawierającej rozmowy z członkami i osobami związanymi z Polskim Stowarzyszeniem na Rzecz Osób z Upośledzeniem Umysłowym w Warszawie. Publikacja składa się z serii wywiadów przeprowadzonych w 2003 r., w 40. rocznicę powstania ruchu rodziców osób niepełnosprawnych intelektualnie. W 2013 r. minęło 50 lat od podjęcia pierwszych inicjatyw związanych $\mathrm{z}$ ukonstytuowaniem się ruchu rodziców na rzecz swych niepełnosprawnych dzieci.

Na gruncie poznawczym podejmowana problematyka stanowi interesujące zagadnienie z perspektywy pedagogiki, polityki spo-

${ }^{1}$ Fragment ten pochodzi z wstępu publikacji B.E. Abramowska, Taka dobra historia... Czterdzieści lat działań rodziców na rzecz osób z niepetnosprawnościa intelektualna, Polskie Stowarzyszenia na Rzecz Osób z Upośledzeniem Umysłowym, Warszawa 2012, s. 10. 
łecznej i socjologii. Celem podjęcia tej tematyki jest próba odpowiedzi na pytanie badawcze związane $\mathrm{z}$ rolą ruchu rodziców $\mathrm{w}$ tworzeniu warunków do emancypacji osób niepełnosprawnych intelektualnie. Wielość współtworzonych działań przez rodziców rodzi pytanie o ich znaczenie $\mathrm{w}$ procesie emancypacji.

Artykuł składa się z trzech części. W pierwszej dokonano charakterystyki zmian paradygmatu oraz rekonstrukcji podejścia emancypacyjnego w odniesieniu do niepełnosprawności. W drugiej osadzono ruch rodziców osób niepełnosprawnych w oparciu wypracowaną teorię i typy ruchów społecznych oraz element konstruowanie się nowych form wspólnotowości. W trzeciej części przedstawiono najważniejsze etapy kształtowania się ruchu rodziców osób niepełnosprawnych, wskazując główne zmiany dokonujące się w czasie.

\section{Niepełnosprawność intelektualna a nowy paradygmat - w stronę emancypacji}

Do lat 80. ubiegłego stulecia funkcjonował medyczny model niepełnosprawności, zgodnie z którym niepełnosprawność traktowano jako defekt, uszkodzenie organizmu, jednocześnie obarczając winą za zaistniały stan rzeczy same osoby niepełnosprawne. Przyjęcie scjentystycznego sposobu postrzegania niepełnosprawności spowodowało powstanie typowego w okresie modernistycznym dualizmu: normalności i nienormalności². Zdaniem Anthony'ego Giddensa modernizm przyczynił się do postrzegania „odchylenia” $\mathrm{w}$ kategorii kontroli ${ }^{3}$. Umocowanie się poststrukturalizmu w opozycji do modernizmu i normatywizmu stanowiło początek konstytuowania się nowej, społecznej perspektywy niepełnosprawności.

2 J. Rzeźnicka-Krupa, Niepetnosprawność $i$ świat społeczny. Szkice metodologiczne, Oficyna Wydawnicza „Impuls”, Kraków 2009, s. 90.

${ }^{3}$ A. Giddens, Nowoczesność i tożsamość. "Ja" i spoteczeństwo w epoce późnej nowoczesności, Wydawnictwo Naukowe PWN, Warszawa 2002, s. 216. 
Przyjęcie społecznego modelu niepełnosprawności znalazło swoje odniesienie $\mathrm{w}$ dokumentach strategicznych wyjaśniających kategorie "zdrowia" czy "choroby" w perspektywie holistycznej. Zgodnie z International Classification of Functioning Disability and Health (ICF) niepełnosprawność intelektualna to wielowymiarowe zjawisko wynikające ze wzajemnych oddziaływań między ludźmi a ich fizycznym i społecznym otoczeni. World Health Organization (WHO) przyjęło klasyfikowanie niepełnosprawności z perspektywy funkcjonowania osób jej doświadczających w środowisku społecznym ${ }^{4}$. W Polsce dynamiczny rozwój socjologii medycyny, zdrowia i choroby oraz pierwsze badania prowadzone przez zespół pod kierunkiem Magdaleny Sokołowskiej ${ }^{5}$ doprowadziły do formowania się społecznego modelu niepełnosprawności. Odpowiedzialność za powstałą dysfunkcję została przeniesiona z osoby niepełnosprawnej na środowisko społeczne. Powstawanie niepełnosprawności rozpoczęto dostrzegać na styku interakcji jednostka - społeczeństwo. Najczęściej przewiało się ono stygmatyzującym charakter instytucji kontroli społecznej, brakiem odpowiedniej infrastruktury czy też tworzeniem barier zarówno $\mathrm{w}$ wymiarze fizycznym, jak i mentalnym ${ }^{6}$. Obecnie niepełnosprawność intelektualną analizuje się w ujęciu krytyczno-emancypacyjnym, a więc zgodnie dyskursem feministycznym 7 . Podstawowymi cechami emancypacji osób

${ }^{4}$ Niepetnosprawność w zwierciadle dorostości, red. R. Kijak, Oficyna Wydawnicza „Impuls", Kraków 2013, s. 8.

${ }^{5}$ W 1978 r. powstała ekspertyza Komitetu Rehabilitacji i Readaptacji Człowieka PAN, zawierająca kompleksowe opracowanie charakteryzujące sytuację ludzi niepełnosprawnych i stan rehabilitacji w Polsce. Inne badanie wraz ze swoim zespołem przeprowadziła M. Sokołowska i dotyczyło onobio-psycho-społeczno-kulturowych uwarunkowań poziomu umysłowego warszawskich nastolatków, znane pod nazwą Warsaw Study (prace M. Sokołowskiej i in. z 1977 r. oraz A. Firkowskiej-Mankiewicz z lat 1993 i 1999).

${ }^{6}$ A. Ostrowska, J. Sikorska, B. Gąciarz, Osoby niepetnosprawne w Polsce w latach dziewięćdziesiątych, Wydawnictwo ISP, Warszawa 2001; A. Ostrowska, Niepetnosprawni w spoteczeństwie. Postawy społeczeństwa polskiego wobec ludzi niepetnosprawnych, Wydawnictwo IFiS PAN, Warszawa 1994.

${ }^{7}$ J. Rzeźnicka-Krupa, op. cit., s. 90 
niepełnosprawnych intelektualnie są z jednej strony tworzenie rzecznictwa skierowanego dla samych niepełnosprawnych, z drugiej natomiast zmierzanie do poprawności politycznej. Po pierwsze kwestionuje się oderwanie ciała i fizyczności człowieka od jego kontekstu społecznego, proponując traktowanie niepełnosprawności intelektualnej jako zjawiska o charakterze kulturowym. Dążenie do emancypacji w takich obszarach jak sfera zawodowa (powstawanie nowych miejsc pracy w obszarze ekonomii społecznej i zatrudnienia wspomaganego, a także w sektorze usług$^{8}$ ), poziom partycypacji (instytucja self-adwokatury ${ }^{9}$ ) czy realizacja potrzeb przez osoby niepełnosprawne intelektualnie, często bagatelizowanych np. seksualnych ${ }^{10}$, stają się coraz częściej faktem. Ponadto w literaturze naukowej przyjęło się definiować i analizować niepełnosprawność intelektualną, wykorzystując nie tylko kryteria pedagogiczne11, psychologiczne $^{12}$, medyczne ${ }^{13}$, ale również społeczne ${ }^{14}$. Drugim z elementów następującej emancypacji jest zmieniająca się nomenklatura w odniesieniu do niepełnosprawności intelektualnej. $\mathrm{Z}$ jednej strony spowodowana jest modą na działania z obszaru inkluzji,

${ }^{8}$ Interesującym przykładem takiego przedsięwzięcia jest powstanie Dobrej Kawiarni na ul. Nowowiejskiego 15 w Poznaniu. Jest to pierwszy lokal w Poznaniu prowadzony przez spółdzielnię socjalną zatrudniającą osoby z niepełnosprawnością intelektualną.

${ }^{9}$ Self-adwokatura (ang. self-advocacy) to bezpośrednie występowanie we własnym imieniu przez osoby z niepełnosprawnością intelektualną - stają się oni rzecznikami własnych spraw. O self-adwokaturze piszą m.in. D. Podgórska-Jachnik i D. Tłoczkowska Ruch self-adwokatów jako rozwijanie kompetencji w zakresie rzecznictwa własnego osób z niepetnosprawnością intelektualna, [w:] Problemy rzecznictwa i reprezentacji osób niepetnosprawnych, red. D. Podgórska Jachnik, Wydaniwnictwo WSP, Łódź 2009.

${ }^{10}$ Niepetnosprawność w zwierciadle dorostości...

${ }^{11}$ K. Kirejczyk K., Upośledzenie umystowe - pedagogika, Wydawnictwo Naukowe PWN, Warszawa.

12 J. Wyczesany J., Pedagogika upośledzonych umysłowo, Oficyna Wydawnicza „Impuls”, Kraków 2004.

${ }^{13}$ K. Kirejczyk, op. cit.

${ }^{14}$ B. Cytowska, Drogi edukacyjne dzieci niepetnosprawnych intelektualnie, Wydawnictwo ITE, Wrocław 2002. 
normalizacji i integracji społecznej wszelkich kategorii uznanych za zmarginalizowane. $\mathrm{Z}$ drugiej natomiast stanowi konsekwencję zwiększenia się świadomości społecznej w traktowaniu osób niepełnosprawnych z poszanowaniem ich godności i autonomii. Określenia takie jak debil, imbecyl, upośledzony choć interesujące z perspektywy historyczno-porównawczej, dziś nie znajdują szerszego zastosowania.

Odmienne podejście prezentuje w swych rozważaniach A. Giddens. Łącząc pojęcia „polityka życia” i „polityka emancypacyjna”, wskazuje na występowanie tzw. „realizmu utopijnego"15, a więc konstruktu teoretycznego wskazującego na brak zasadności w stosowaniu podejścia emancypacyjnego wobec osób niepełnosprawnych intelektualnie. Zgodnie $\mathrm{z}$ tym podejściem, pomimo podejmowanych działań asymilacyjnych, włączających i zmian dokonujących się w publicznym dyskursie, nie jest możliwe zrównanie statusu osób niepełnosprawnych intelektualnie $\mathrm{z}$ resztą społeczeństwa, choćby z uwagi na ograniczenia wielu ról, których nie będą mogły te osoby podjać. Pomimo tworzenia nowych miejsc pracy na otwartym rynku pracy, osoby z niepełnosprawnością intelektualną nigdy nie będą mogły pracować w konkretnych branżach.

Należy zaznaczyć, iż rozwinięciem modelu społecznego został model polityczny (tabela 1), zgodnie z którym przyznano katalog praw zrównujących status osób niepełnosprawnych intelektualnie $\mathrm{z}$ resztą społeczeństwa ${ }^{16}$, rozbudowano infrastrukturę i system wsparcia społecznego. Dokonujące się przeobrażenia można określić jako postępującą zmianę społeczną ${ }^{17}$. Na każdym etapie dokonujących się przeobrażeń społecznych, osobom niepełnosprawnym intelektualnie towarzyszyli ich rodzice, z jednej strony wspierając swych podopiecznych, z drugiej natomiast wyznaczając standardy i kierunki polityki społecznej, prorodzinnej, zabezpieczenia społecznego itd.

15 A. Giddens, op. cit., s. 297, 292.

16 Przyjęta przez ONZ i ratyfikowana w wielu państwach Konwencji o prawach osób niepełnosprawnych, którą Polska ratyfikowała w roku 2012.

17 J. Macionis, Sociology, Prentice Hall, Englewood Cliffs 1987. 
Tabela 1. Przejście do roli pacjent do obywatela - od modelu medycznego do politycznego

\begin{tabular}{|l|l|l|l|}
\hline & \multicolumn{1}{|c|}{$\begin{array}{c}\text { ERA INSTYTU- } \\
\text { CJONALIZMU }\end{array}$} & $\begin{array}{l}\text { ERA DEIZNSTY- } \\
\text { TUCJONALIZMU }\end{array}$ & \multicolumn{1}{|c|}{$\begin{array}{c}\text { ERA UCZEST- } \\
\text { NICTWA }\end{array}$} \\
\hline TYP MODELU & $\begin{array}{l}\text { Model medyczny - } \\
\text { instytucjonalny }\end{array}$ & $\begin{array}{l}\text { Model rozwojowy, } \\
\text { rehabilitacyjny, } \\
\text { konsumencki }\end{array}$ & $\begin{array}{l}\text { Model obywatelski } \\
\text { - indywidualnego } \\
\text { wspierania }\end{array}$ \\
\hline $\begin{array}{l}\text { Kto jest w centrum } \\
\text { uwagi? }\end{array}$ & Pacjent & $\begin{array}{l}\text { Klient - konsu- } \\
\text { ment }\end{array}$ & $\begin{array}{l}\text { Obywatel - czło- } \\
\text { nek społeczności }\end{array}$ \\
\hline Miejsce pobytu & Zakład & $\begin{array}{l}\text { Hostel, szkoła } \\
\text { specjalna, warsztat } \\
\text { terapii zajęciowej }\end{array}$ & $\begin{array}{l}\text { Dom rodzinny, } \\
\text { publiczna szkoła, } \\
\text { zakład pracy }\end{array}$ \\
\hline $\begin{array}{l}\text { Na czym polega } \\
\text { pomoc? }\end{array}$ & $\begin{array}{l}\text { Sprawowanie } \\
\text { opieki }\end{array}$ & $\begin{array}{l}\text { Realizacja progra- } \\
\text { mu }\end{array}$ & $\begin{array}{l}\text { Indywidualne } \\
\text { wspieranie }\end{array}$ \\
\hline $\begin{array}{l}\text { Kto kontroluje } \\
\text { realizacje progra- } \\
\text { mu? }\end{array}$ & $\begin{array}{l}\text { Profesjonalista - } \\
\text { zwykle lekarz }\end{array}$ & $\begin{array}{l}\text { Interdyscyplinarny } \\
\text { zespół }\end{array}$ & Sama jednostka \\
\hline $\begin{array}{l}\text { Co jest prioryte- } \\
\text { tem? }\end{array}$ & $\begin{array}{l}\text { Podstawowe po- } \\
\text { trzeby }\end{array}$ & $\begin{array}{l}\text { Rozwijanie spraw- } \\
\text { ności, kontrola } \\
\text { zachowania }\end{array}$ & $\begin{array}{l}\text { Samostanowienie } \\
\text { i relacje z innymi }\end{array}$ \\
\hline Co jest celem? & $\begin{array}{l}\text { Opieka i/lub le- } \\
\text { czenie }\end{array}$ & $\begin{array}{l}\text { Zmiana zachowa- } \\
\text { nia jednostek }\end{array}$ & $\begin{array}{l}\text { Zmiana postaw } \\
\text { społecznych śro- } \\
\text { dowska }\end{array}$ \\
\hline
\end{tabular}

Źródło: J. Knoll, From Community-Based Alternatives to Inclusion Communities, "Inclusive Communities" 1992, 1(1); V.J. Bradley, Evolution of a new service paradigm, [w:] Creating individual support for people with development disabilities, red. V.J. Bradley, J.W.A. Shbaugh, B.C. Baney, Paul H. Brookies Publishing Co., Baltimore, London, Sydney 1994.

\section{Ruchy społeczne - nowe wspólnoty czy sieci społeczne?}

Charakterystykę i rys historyczny inicjatyw podejmowanych przez rodziców osób niepełnosprawnych należy poprzedzić wyjaśnieniem terminu "ruch społeczny”. Zasygnalizowana w poprzednim akapicie zmiana społeczna stanowi element niezbędny do szczegółowego wyjaśnienia tego określenia. 
Na gruncie socjologii, termin ten wyjaśniali m.in. H. Blumer, podkreślając element ustanowienia nowego porządku życia ${ }^{18}$, A. Touraine, odnosząc ruchy społeczne do „historycznych jednostek działających"19 czy M. Adamson i S. Borgos, prezentując wizję konfliktu i ruchów masowych jako podstawowych podmiotów zmiany społecznej20. Proponuję wskazać konstytutywne komponenty ruchów społecznych, na które zwraca uwagę P. Sztompka ${ }^{21}$. Ruch społeczny stanowi zbiorowość, relatywnie rozproszoną, cechującą się wysokim poziomem spontaniczności, działającą razem, posiadającą wspólny cel - dokonanie zmiany. Można wskazać typy ruchów społecznych ${ }^{22}$, uwzględniając zróżnicowane kryteria, odnosząc je tym samym do inicjatyw podejmowanych przez rodziców osób niepełnosprawnych intelektualnie. Pod względem zakresu planowanej zmiany należy wyszczególnić ruchy radykalne i reformatorskie. Pierwsze dążą do przekształcenia całego społeczeństwa, drugie natomiast do dokonania $\mathrm{w}$ nim zmian. $\mathrm{W}$ odniesieniu do tego kryterium ruch rodziców osób niepełnosprawnych można określić jako ruch reformatorski. Drugim kryterium różnicującym ruchy społeczne jest jakość zamierzonej zmiany. Niektóre ruchy zorientowane są na przyszłość, dokonywane pozytywnych zmian, kładąc nacisk na innowacje, podczas gdy inne dążą do odbudowania instytucji, norm, zwyczajów funkcjonujących w przeszłości, które na skutek próby czasu uległy zburzeniu. Pierwsze zostaną nazwane ruchami postępowymi, drugie natomiast konserwatywnymi (zwyczajowymi). Zgodnie z tym kryterium ruch rodziców osób niepełnosprawnych to ruch postępowy.

18 H. Blumer, Coolective behavior, [w:] Principles of Sociology, red. A. McClung Lee Random House, Nowy Jork 1951.

19 A. Touraine, The self-production of Society, University of Chicago Press, Chicago 1977, s. 298.

${ }^{20}$ M. Adamson, S. Borgos, This Mighty Dream: Social Protest Movements in the United States, Routledge \& Kegan Paul, Boston 1984.

21 P. Sztompka, Socjologia. Analiza społeczeństwa, Wydawnictwo „Znak”, Kraków 2005, s. 236.

22 Ibidem, s. 261-265. 
Jeszcze innym kryterium różnicującym ruchy społeczne jest tzw. „wektor" planowanej zmiany. Większość ruchów, w tym również skupiających rodziców osób niepełnosprawnych, ma charakter pozytywny, a więc dąży do dokonania zmiany. Inne natomiast mają wektor negatywny, a zatem starają się zapobiec dokonującym zmianom.

Ruchy społeczne mogą się także różnić pod względem właściwej dla nich „logiki” działania ${ }^{23}$. Ruchy funkcjonujące w oparciu o logikę instrumentalną dążą do zdobycia władzy w celu dokonania zakładanych zmian. Celem ich działania jest sprawowanie kontroli politycznej, a z czasem przekształcenie się w grupę nacisku lub partię polityczną. Inne ruchy opierają swe działania na logice „ekspresyjnej" i jak wskazuje P. Sztompka:

(...) usiłują potwierdzić swą obecność, uzyskać akceptację dla propagowanych przez siebie wartości lub sposobów życia, zyskać autonomię, równe prawa, emancypację kulturalną i polityczną dla swoich członków lub szerszego elektoratu ${ }^{24}$.

Logika „ekspresyjna” bliższa jest funkcjonowaniu ruchów rodziców osób niepełnosprawnych intelektualnie.

Nawiązując do myśli A. Touraine'a25, w późnej nowoczesności mamy do czynienia z tzw. "nowymi ruchami społecznymi” (ang. new social movements). W przeciwieństwie do "starych”, odnoszących się do aktywności klasy robotniczej i interesów ekonomicznych, współczesne ruchy stawiają sobie za cel ingerencję w elementy struktury państwa takie jak polityka, ekonomia, biurokracja, jednakże przedmiot ich działań ma wymiar "postmaterialistyczny". W przeciwieństwie do relacji o charakterze ekonomicznym, w centrum zainteresowania nowych ruchów znalazły się m.in. autonomia jednostki, jakość życia, tożsamość kulturowa, wolność od czynni-

23 D. Rucht, Themes, logics, and arenas of social movements: a structural approach, [w:] International Social Movement Research, t. 1, red. L. Kriesberg, JAI Press, Syracuse 1988.

24 P. Sztompka, op. cit., s. 263.

25 A. Touraine, The Voice and the Eye, Cambridge University Press, Cambridge 1981. 
ków ryzyka. Osoby zaangażowane we współczesne ruchy społeczne nie reprezentują konkretnej klasy społecznej, lecz łączy je podobieństwo sytuacji życiowej, doświadczanego problemu, wspólnie podzielanych wartości. Należy zaznaczyć, że współczesne ruchy to najczęściej zdecentralizowane struktury, w większości przypominające bardziej sieci niż hierarchiczne struktury.

W odniesieniu do współczesnych stosunków łączących rodziców osób niepełnosprawnych zasadne jest wskazanie dwóch tendencji: typowej dla postmodernizmu indywidualizacji życia ${ }^{26}$ oraz reaktywacji przednowoczesnej przynależności do wspólnoty. W świetle aktualnego stanu literatury zagadnienie rozróżnienia stosunków społecznych zostało już podjęcie przez klasyka socjologii humanistycznej F. Töenniesa27, który zarysował tendencję do odchodzenia społeczeństw Europy kapitalistycznej od Gemeinschaft (wspólnoty) na rzecz Gesellschaft (stowarzyszeń). Odmiennego punkt widzenia przyjmuje M. Maffesoli28, który choć w swoich rozważaniach proponuje podobną dwubiegunowość i podział stosunków społecznych na społeczność (social) i wspólnotę (socialitê). Zgodnie z jego podejściem ludzie odchodzą od społeczności na rzecz wspólnoty, budując więzi i bliższe relacje, choć nie oznacza to powrotu do tradycyjnych form wspólnotowości. Jednostka nie przynależy do wspólnoty, określanej przez Maffesolego jako „nowe plemię" ze względu na urodzenie, lecz na skutek świadomej decyzji.

P. Morris ${ }^{29}$ rozróżnia wspólnoty na: przypisania, charakteryzujące się zamkniętą strukturą skupiającą członków ze względu na pochodzenie oraz uzgodnienia, do których członkowie przystępują

26 U. Beck, Społeczeństwo ryzyka: $w$ drodze do innej nowoczesności, Wydawnictwo Naukowe "Scholar", Warszawa 2004.

${ }^{27}$ F. Toënnies, Wspólnota i stowarzyszenie, Wydawnictwo Naukowe PWN, Warszawa 1988.

${ }_{28}$ M. Maffesoli, Le temps des tribus. Le déclin de l'individualisme dans les sociétés postmodernes, La Table Ronde, Paris 2000.

29 P. Morris, Community beyond tradition, [w:] Detraditionalization. Critical Reflections on Authority and Identity, red. P. Heelas, S. Lash, P. Morris, Blackwell Publishers, Oxford 1996. 
poprzez świadomy, indywidualny wybór. Tradycyjne wspólnoty przypisania funkcjonowały na poziomie lokalnym i cechowały je silne osadzenie w czasie. Identyfikacja członków wynikała z potrzeby przynależności. Wspólnoty uzgodnienia cechuje oderwanie od kontekstu czasowo-przestrzennego, transnarodowy oraz wyobrażeniowy charakter polegający na częstym zastępowaniu kontaktu twarzą w twarz alternatywnymi formami komunikacji ${ }^{30}$.

Zdaniem M. Marody i A. Gizy-Poleszczuk ${ }^{31}$ jednostka, która jest kulturowo zakorzeniona $\mathrm{w}$ indywidualizmie, realizuje własną indywidualność poprzez przynależność do wspólnoty. Według A. Wittel ${ }^{32}$ powstawanie nowych form integracji społecznej może implikować organizacja nowego rodzaju relacji społecznych, określanych jako uspołecznienie sieciowe (ang. network sociality). Polega ono na dążeniu do osiągnięcia konkretnego celu, do wywołania określonej zmiany społecznej. Relacje sieciowe są elastyczne, natychmiastowe, bardzo intensywne ale z drugiej strony cechują się tymczasowością. Otwarta struktura grupy sprawia, że w momencie osiągnięcia celu relacje zostają zakończone, a jednostka wytwarza więzi w grupie skupionej na realizacji innego przedsięwzięcia. Wielość i różnorodność ruchów podejmowanych przez rodziców utrudnia znalezienie jednej odpowiedzi na pytanie odnoszące się to tożsamości, podzielanych wartości oraz głównego celu, do którego dążą. Inicjatywy podejmowane prze rodziców osób niepełnosprawnych mogą wynikać ze wspólnie podzielanych poglądów, gotowości do podjęcia świadomej decyzji oraz mogą być podyktowane chęcią osiągnięcia konkretnego celu. Nawiązując do rozróżnienia P. Morrisa33, są to

${ }^{30}$ B. Anderson, Wspólnoty wyobrażone. Rozważania o źródtach i rozprzestrzenianiu się nacjonalizmu, Wydawnictwo Znak, Kraków 1997.

${ }^{31}$ M. Marody, A. Giza-Poleszczuk, Przemiany więzi społecznych. Zarys teorii zmiany społecznej, Wydawnictwo Nakowe Scholar, Warszawa 2004.

32 A. Wittel, Towards a network society, „Theory, Culture and Society” 2001, t. 18, nr 6.

33 P. Morris, Community beyond tradition, [w:] Detraditionalization. Critical Reflections on Authority and Identity, red. P. Heelas, S. Lash, P. Morris, Blackwell Publishers, Oxford 1996. 
wspólnoty uzgodnienia. Mogą funkcjonować w oparciu o bliskie, bezpośrednie stosunki łączące ich członków (np. wspólnota „Wiara i Światło" 34 ), ale również w oparciu o komunikację zapośredniczoną w obrębie komunikatorów online, grup samopomocowych w przestrzeni wirtualnej czy forów internetowych ${ }^{35}$ (np. forum Ogólnopolskiego Stowarzyszenia Rodzin Osób Niepełnosprawnych „Razem Możemy Więcej"36). Na skutek rosnącej popularności portali społecznościowych, dostępności nowych technologii i aplikacji mobilnych rodzice osób niepełnosprawnych coraz częściej tworzą grupy na portalach takich jak Facebook ${ }^{37}$.

\section{Początki kształtowania się ruchu rodziców osób niepełnosprawnych - samopomoc, samoorganizacja, samorządność}

J. Hrynkiewicz wskazuje, że sfery działania ruchów i inicjatyw społecznych obejmują te dziedziny, które charakteryzują się brakiem odpowiednich instytucji, ich niewłaściwym funkcjonowaniem oraz niemożnością zaspokojenia istotnych potrzeb ${ }^{38}$. Ruchy

34 Strona internetowa wspólnoty „Wiara i Światło”: http://ekai.pl/wspolnoty/ ruch-wiara-i-swiatlo/ [21.11.2015].

35 Więcej znajduje się w moim artykule: Koperski Ł, E-pomoc dla e-rodziców dzieci $z$ niepetnosprawnościa, „Niepełnosprawność i Rehabilitacja”3/2014, Instytut Rozwoju Służb Społecznych, s. 107-118.

36 Strona internetowa, na której znajduje się forum: http://www.razem-moze my-wiecej.com.pl/?page=forum [21.11.2015].

37 W 2015 r. prowadziłem badania wśród rodziców osób niepełnosprawnych, tworzących grupy wsparcia na portalu społeczni ościowym Facebook. Oto najważniejsze wnioski z badań: (1) grupy te stwarzają możliwość podzielenia się cennymi informacjami i poradami pomiędzy rodzicami, którzy znajdują się podobnym położeniu; (2) wsparcie online może być realizowane w oderwaniu od ograniczeń czasowo-przestrzennych; (3) uczestnictwo w obrębie grup umożliwia realizację nie tylko funkcji o charakterze pomocowym, ale przede wszystkim afiliacyjnym.

38 J. Hrynkiewicz, Ruchy i inicjatywy społeczne w sferze socjalnej, [w:] Zaradność społeczna: $z$ badań nad społecznymi inicjatywami w dziedzinie rozwiązywania proble- 
społeczne podejmowane $\mathrm{w}$ latach 80 . przez rodziców osób niepełnosprawnych wynikały $\mathrm{z}$ następujących powodów: (1) brak odpowiednich instytucji wsparcia rodziny, (2) niedostatecznej liczny takich instytucji, (3) niskiej oceny działania tych instytucji, (4) trudności w zapewnieniu opieki we własnym zakresie, (5) pojawienie się nowych, dotychczas nieznanych schorzeń, (6) wyższa świadomość rodziców związana z okolicznościami pojawienia się niepełnosprawnego dziecka ${ }^{39}$. Można odnieść wrażenie, że pomimo ćwierćwiecza od pojawienia się pierwszych publikacji dotyczących funkcjonowania rodziców osób niepełnosprawnych, przyczyny tworzenia prze nich ruchów są wciąż aktualne. $Z$ jednej strony należy je ulokować $\mathrm{w}$ środowisku społecznym (instytucjach, infrastrukturze), które niedostatecznie odpowiada na pojawiające się problemy. $Z$ drugiej strony tworzenie ruchów społecznych przez rodziców jest wyrazem wzrastającego poziomu wiedzy zarówno $\mathrm{w}$ kontekście doświadczanych trudności oraz posiadanych prawa.

Historia pierwszych inicjatyw podejmowanych przez rodziców osób niepełnosprawnych sięga pierwszej połowy lat 60. W $1962 \mathrm{r}$. Ewa i Roman Garliccyz Warszawy nawiązali pierwsze oficjalne kontakty $\mathrm{z}$ innymi rodzicami $\mathrm{w}$ celu organizacji opieki nad dziećmi młodzieżą i osobami dorosłymi z głębszą niepełnosprawnością intelektualną. Rok po tym wydarzeniu, ukazał się artykuły: Bolesny temat (w tygodniku ilustrowanym „Świat”) oraz Spontaniczna inicjatywa - na razie bez odpowiedzi (w "Życiu Warszawy") opisujące funkcjonowanie i zmaganie się z trudnościami przez rodziców posiadających dzieci niepełnosprawne ${ }^{40}$. Inicjatywy podejmowane przez rodziców istniały już od lat 50. w Danii, Holandii, Norwegii, Anglii

mów Polski lat osiemdziesiątych, red. J. Kwaśniewski, R. Sobiech, J. Zamecka, Polskie Towarzystwo Socjologiczne, Zakład Narodowy im. Ossolińskich, Wrocław 1990, s. 167.

39 J. Hrynkiewicz, Ruchy i inicjatywy społeczne w sferze socjalnej, [w:] Zaradność spoteczna..., s. 170 .

40 E.B. Abramowska, op. cit., s. 13. 
czy Stanach Zjednoczonych ${ }^{41}$. W Polsce w 1963 r. przy Zarządzie Głównym Towarzystwa Przyjaciół Dzieci powstał Komitet Pomocy Dzieciom Specjalnej Troski (KPDST). W tym samym roku powstały oddziały koła w Katowicach, Krakowie, Poznaniu, Gdańsku i Częstochowie. Lata 70. i 80. to systematyczny wzrost liczby nowych inicjatyw podejmowanych przez rodziców. Rozpoczęto tworzyć turnusy rehabilitacyjne dla rodzin $\mathrm{z}$ małymi dziećmi. Podjęto temat wczesnej interwencji $\mathrm{w}$ odniesieniu do niepełnosprawności intelektualnej oraz oficjalnie podkreślono potrzebę psychicznego wspierania rodziców dzieci niepełnosprawnych. Ciekawą inicjatywą, rozpoczętą $w$ drugiej połowie lat 70 . była audycja na antenie Polskiego Radia pt. "Nie jesteście sami”, skierowana dla rodziców dzieci niepełnosprawnych. W 1983 r., Komitet Pomocy Dzieciom Specjalnej Troski został przemianowany na Ko-

${ }^{41}$ Badania empiryczne dotyczące tworzenia przez rodziców ruchów społecznych, organizacji i inicjatyw obywatelskich realizowano m.in. w następujących państwach: Francja: rola stowarzyszeń rodziców wpowstawaniu projektów naukowych dotyczących przyczyn powstawania niepełnosprawności intelektualnej oraz ośrodków wsparcia (Billé M., Niepetnosprawność intelektualna. Od ignorancji do obywatelstwa - działalność stowarzyszeń rodziców, [w:] Wptyw ruchu rodziców osób z niepetnosprawnościa intelektualna na rozwój nauki i życie spoteczne. Raport $z$ badań, Warszawa 2014); Litwa: powstanie Litewskiego Towarzystwa Opieki nad Osobami z Niepełnosprawnością Intelektualną "Viltis” (poprawa warunków i jakości życia ich dzieci, przywracania społeczeństwu osób niepełnosprawnych) (Olesova N., Wptyw społeczeństwa obywatelskiego na jakość życia osób z niepetnosprawnościa intelektualna, [w:] Wpływ ruchu rodziców osób z niepetnosprawnością...); Włochy: pierwsze stowarzyszenia rodziców osób niepełnosprawnych intelektualnie powstały w latach 50. Współcześnie rolą organizacji pozarządowych jest wspieranie rodzin $\mathrm{w}$ otwieraniu się na społeczeństwo (Bosisio Fazzi L., Stowarzyszenia rodziców we Wtoszech. Historia, rola i funkcja społeczna w zapewnieniu praw i dobrej jakości życia osób z niepełnosprawnością intelektualną, [w:] Wptyw ruchu rodziców osób z niepetnosprawnością...); Stany Zjednoczone: doskonale rozwinięta instytucja rzecznictwa, reprezentacji interesów oraz rola rodziców w tworzeniu i doskonaleniu self-adwokatury (Foster M., Taub Dryndak D., Rola rzecznictwa i organizacji typu non-profit w tworzeniu i wdrażaniu ustug dla osób z niepetnosprawnością intelektualna w Stanach Zjednoczonych, [w:] Wptyw ruchu rodziców osób z niepetnosprawnościa...). 
mitet Pomocy Osobom z Upośledzeniem Umysłowym, którym kierować rozpoczęli K. Mrugalska, T. Dłuska i I. Wald. Dzięki usilnym staraniom działaczy Komitetu PDST wprowadzono kilka udogodnień dla rodziców, m.in. wydłużony urlop wychowawczy, zasiłek pielęgnacyjny, stały zasiłek dla osób, które nabyły niepełnosprawność przed 18. rokiem życia i nie mogły podjąć zatrudnienia42. Na przełomie transformacji polityczno-gospodarczej w latach 1990-1991 doszło do odłączenia się Komitetu z Towarzystwa Przyjaciół Dzieci. W jego miejsce zarejestrowano Polskie Stowarzyszenie na Rzecz Osób z Upośledzeniem Umysłowym, pierwszą organizację pozarządową w Polsce wpierającą osoby niepełnosprawne intelektualnie i ich rodziny ${ }^{43}$. Począwszy od początku lat 90. powołano wiele podmiotów podejmujące tematykę niepełnosprawności w rodzinie ${ }^{44}$, często działających po dziś dzień, które wcześniej funkcjonowały jako koła, komitety, nieformalne grupy bądź wspólnoty. Obecnie najczęściej rozwijanymi obszarami działania są kwestie edukacji, wsparcia, aktywizacji społeczno-zawodowej, włączania w główny nurt życia społecznego, rehabilitacji społecznej, czy wreszcie polityki społecznej.

Od roku 2014 jesteśmy świadkami tworzenia przez rodziców osób niepełnosprawnych ogólnopolskiej platformy sprzeciwu wobec obecnego systemu zabezpieczenia socjalnego skierowanego dla osób niepełnosprawnych i ich rodzin. 25 lat po obradach Okrągłego Stołu, z inicjatywy rodziców osób niepełnosprawnych zorganizowano cykl spotkań przy okrągłym stole, których tematem przewodnim była sytuacja osób niepełnosprawnych i ich rodzin w Polsce. W spotkaniach wzięli udział przedstawiciele zróżnicowanych środowisk, m.in. resortów zdrowia, edukacji, finansów, pracy i poli

42 E.B. Abramowska, op, cit, s. 11-14.

43 Ibidem, s. 16-26.

44 Przykłady organizacji pozarządowych: Stowarzyszenie Na Tak (Poznań), Ogólnopolskie Stowarzyszenie Rodzin Osób Niepełnosprawnych „Razem Możemy Więcej” (Kędzierzyn-Koźle), Stowarzyszenie Rodziców i Opiekunów Dzieci, Młodzieży i Osób Niepełnosprawnych i Przewlekle Chorych „Oni są” (Kąty), Stowarzyszenie Rodziców i Osób Niepełnosprawnych „Wsparcie” (Czechowice-Dziedzice). 
tyki społecznej, samorządowcy, Rzecznik Praw Dziecka, Rzecznik Praw Obywatelskich, przedstawiciel Rady Działalności Pożytku Publicznego, Państwowego Funduszu Rehabilitacji Osób Niepełnosprawnych, przedstawiciele organizacji pozarządowych ${ }^{45}$ oraz rodzice osób niepełnosprawnych. Wśród postulatów rodziców osób niepełnosprawnych znalazły się m.in. podniesienie kwoty dofinansowania do turnusów rehabilitacyjnych i refundowanego sprzętu medycznego, zwiększenie liczby godzin darmowej rehabilitacji i dostępu do specjalistycznych placówek po ukończonej edukacji dziecka oraz przekazywania subwencji oświatowej dla niepełnosprawnych dzieci bezpośrednio szkołom. Ponadto kwestię sporną stanowi wysokość świadczeń rodzinnych - świadczenia pielęgnacyjnego, zasiłku dla opiekuna i specjalnego zasiłku opiekuńczego. Obecnie świadczenie pielęgnacyjne w wysokości 1200 zł przysługuje rodzicom niepełnosprawnych dzieci, jeśli ich niepełnosprawność powstała przed ukończeniem 18 lat (lub 25 lat, gdy się uczą). Warunkiem otrzymywania świadczenia jest rezygnacja $\mathrm{z}$ pracy $\mathrm{w}$ celu opieki nad dzieckiem. Nie obowiązuje w tym przypadku kryterium dochodowe. Inne zasady odnoszą się do opiekunów osób, których niepełnosprawność powstała po osiągnięciu przez nie dorosłości. Otrzymują oni zasiłek dla opiekuna w wysokości 520 zł. Zgodnie z projektem ustawy z 2015 r., wszyscy opiekunowie osób niepełnosprawnych rezygnujący z pracy zawodowej mogliby otrzymywać świadczenie pielęgnacyjne zależne od kryterium dochodowego (1000 zł netto na osobę w rodzinie), a wysokość - od wieku niepełnosprawnego. Opiekunom osób, które nie ukończyłyby 18 lub 25 lat przysługiwałoby świadczenie w wysokości 1200 zł w roku 2015 i 1300 zł od 2016 r., natomiast opiekunom dorosłych osób niepełnosprawnych świadczenie wynoszące 800 zł netto.

45 Piotr Pawłowski (Integracja), Anna Woźniak-Szymańska (Polski Związek Niewidomych), Anna Dymna (Fundacja Mimo Wszystko), ks. Tadeusz Isakowicz-Zaleski (Fundacja im. Brata Alberta), Krystyna Mrugalska (honorowa prezes Polskiego Stowarzyszenia na Rzecz Osób z Upośledzeniem Umysłowym), Joanna Janocha i Barbara Abramowska (obie: PSOUU), Bartosz Mioduszewski (Fundacja Aktywizacja). 
Ruch rodziców osób niepełnosprawnych intelektualnie spełnia szereg funkcji, odnoszących się zarówno do bezpośrednich działań pomocowych, ale również integrujących i wzmacniających więzi między rodzicami - aktorami społecznymi (tabela 2).

Tabela 2. Funkcje ruchu rodziców osób niepełnosprawnych

\begin{tabular}{|l|l|}
\hline \multicolumn{1}{|c|}{ Funkcja } & \multicolumn{1}{|c|}{ Wyjaśnienie } \\
\hline Wspierająca & $\begin{array}{l}\text { Organizacja wsparcia społecznego dla osób niepełnospraw- } \\
\text { nych i ich rodziców (opiekunów) }\end{array}$ \\
\hline Kontrolna & $\begin{array}{l}\text { Kontrola instytucji i realizowanych działań w obszarze } \\
\text { wspierania osób niepełnosprawnych i ich rodzin }\end{array}$ \\
\hline Afiliacyjna & $\begin{array}{l}\text { Możliwość współtworzenia ruchu, przynależenie do niego, } \\
\text { podejmowania nowych inicjatyw }\end{array}$ \\
\hline Kreacyjna & $\begin{array}{l}\text { Współtworzenie standardów wsparcia osób niepełnospraw- } \\
\text { nych intelektualnie i ich rodzin }\end{array}$ \\
\hline Integracyjna & $\begin{array}{l}\text { Integracja rodziców osób niepełnosprawnych intelektualnie; } \\
\text { możliwośćnawiązywania nowych znajomości, często } \\
\text { woderwaniu od czasu i przestrzeni }\end{array}$ \\
\hline Informacyjna & $\begin{array}{l}\text { Przekazywanie informacji związanych z zagadnieniem } \\
\text { niepełnosprawności, działaniami pomocowymi bądź ich } \\
\text { brakiem }\end{array}$ \\
\hline $\begin{array}{l}\text { Zabieranie głosu w publicznym dyskursie, poprzez przed- } \\
\text { stawianie społeczeństwu problemu z perspektywy rodzica } \\
\text { (opiekuna) osoby niepełnosprawnej }\end{array}$ \\
\hline
\end{tabular}

Źródło: Opracowanie własne

\section{Podsumowanie}

Współczesne inicjatywy podejmowane przez rodziców osób niepełnosprawnych, niezależnie od ich skuteczności dowodzą, że mamy do czynienia z ruchem społecznym o specyficznej strukturze i dynamice funkcjonowania. Pomimo wysokiej populacji, rodzice osób niepełnosprawnych stanowią kategorię niezwykle dobrze zorganizowaną i spójną w swych założeniach. Współtworzenie prze- 
strzeni do nawiązywania nowych relacji, w odniesieniu do kontaktów bezpośrednich oraz zapośredniczonych w mediach sprzyja budowaniu zaufania, umacniania wsparcia społecznego oraz poszukiwania alternatywnych metod działania. Idee towarzyszące działaniom rodziców z jednej strony stanowią odpowiedź na nieefektywne funkcjonowanie systemu wsparcia w wymiarze instytucjonalnym poprzez opór, z drugiej zaś nawiązują do podstawowych wartości, jak sprawiedliwość społeczna czy przeciwdziałanie marginalizacji.

Wracając do pytania postawionego na początku artykułu o rolę ruchu rodziców w tworzeniu warunków sprzyjających emancypacji osób niepełnosprawnych, można wskazać dwa scenariusze.

Po pierwsze ruch rodziców może przyczyniać się do emancypacji osób niepełnosprawnych, poprzez (1) prezentowanie ich jako autonomicznych jednostek, które zasługują na równe traktowanie, (2) wspomaganie ich autonomii oraz (3) wzmacnianie poczucia sprawstwa. Inicjatyw podejmowane przez rodziców, bądź założone przy ich udziale podmioty, dążą do podkreślania roli społecznozawodowej osób niepełnosprawnych intelektualnie. Zmianie ulega medialny wizerunek samych niepełnosprawnych, jako osób posiadających talenty, umiejętności, zasoby czy kompetencje społeczne na wysokim poziomie.

Po drugie ruch rodziców może jednocześnie przyczyniać się do ograniczeniami emancypacji osób niepełnosprawnych intelektualnie. Położenie akcentu na kwestię socjalną może skutkować przedstawianiem i odbieraniem niepełnosprawnych jako niewyuczalnych, niesamodzielnych, potrzebujących ciągłej opieki - w konsekwencji jako kategorii niezaradnej życiowo i społecznie.

Bibliografia

Abramowska E.B., Taka dobra historia... Czterdzieści lat działań rodziców na rzecz osób $z$ niepetnosprawnościq intelektualną, Polskie Stowarzyszenia na Rzecz Osób z Upośledzeniem Umysłowym, Warszawa 2013. 
Anderson B., Wspólnoty wyobrażone. Rozważania o źródłach i rozprzestrzenianiu się nacjonalizmu, Wydawnictwo Znak, Kraków 1997.

Adamson M., Borgos S., This Mighty Dream: Social Protest Movements in the United States, Routledge \& Kegan Paul, Boston 1984.

Beck U., Społeczeństwo ryzyka: w drodze do innej nowoczesności, Wydawnictwo Naukowe "Scholar”, Warszawa 2004.

Billé M., Niepetnosprawność intelektualna. Od ignorancji do obywatelstwa - dziatalność stowarzyszeń rodziców, [w:] Wptyw ruchu rodziców osób z niepetnosprawnościa intelektualna na rozwój nauki i życie społeczne. Raport z badań, Warszawa 2014.

Bosisio Fazzi L., Stowarzyszenia rodziców we Włoszech. Historia, rola i funkcja społeczna $w$ zapewnieniu praw i dobrej jakości życia osób z niepetnosprawnością intelektualna, [w:] Wpływ ruchu rodziców osób z niepetnosprawnościq intelektualną na rozwój nauki i życie społeczne. Raport z badań, Warszawa 2014.

Blumer H., Coolective behavior, [w:] Principles of Sociology, Random House, red. A. McClung Lee, Nowy Jork 1951.

Bradley, V.J. Evolution of a new service paradigm, [w:] Creating individual support for people with development disabilities, red. V.J. Bradley, J.W.A. Shbaugh, B.C. Baney, Paul H. Brookies Publishing Co., Baltimore, London, Sydney 1994.

Firkowska-Mankiewicz A., Zmiana paradygmatu w postrzeganiu osoby z niepetnosprawnościa intelektualna - od pacjenta do obywatela, [w:] Osoby niepetnosprawne a media cyfrowe. Z pogranicza teorii i praktyki, red. A. Andrzejwska, J. Bednarek, Wydawnictwo APS, Warszawa 2010.

Foster M., Taub Dryndak., D., Rola rzecznictwa i organizacji typu non-profit w tworzeniu i wdrażaniu ustug dla osób z niepetnosprawnościa intelektualna w Stanach Zjednoczonych, [w:] Wptyw ruchu rodziców osób z niepetnosprawnościa intelektualna na rozwój nauki i życie społeczne. Raport z badań, Warszawa 2014.

Giddens A., Nowoczesność i tożsamość. "Ja" i społeczeństwo w epoce późnej nowoczesności, Wydawnictwo Naukowe PWN, Warszawa 2002.

Hrynkiewicz J., Ruchy i inicjatywy społeczne w sferze socjalnej, [w:] Zaradność społeczna: $z$ badań nad społecznymi inicjatywami w dziedzinie rozwiązywania problemów Polski lat osiemdziesiątych, red. J. Kwaśniewski, R. Sobiech, J. Zamecka, Polskie Towarzystwo Socjologiczne, Zakład Narodowy im. Ossolińskich, Wrocław 1990.

Knoll J., From Comunity-Based Alternatives to Inclusion Communities, "Inclusive Communities" 1 (1).

Koperski Ł., E-pomoc dla e-rodziców dzieci z niepetnosprawnościa, „Niepełnosprawność i Rehabilitacja” nr 3, Instytut Rozwoju Służb Społecznych, Warszawa.

Macionis J., Sociology, Prentice Hall, Englewood Cliffs 1987.

Maffesoli M., Le temps des tribus. Le déclin de l'individualisme dans les sociétés postmodernes, La Table Ronde, Paris 2000.

Marody M., A. Giza-Poleszczuk, Przemiany więzi społecznych. Zarys teorii zmiany społecznej, Wydawnictwo Nakowe Scholar, Warszawa 2004. 
Morris P., Community beyond tradition, [w:] Detraditionalization. Critical Reflections on Authority and Identity, red. P. Heelas, S. Lash, P. Morris, Blackwell Publishers, Oxford 1996.

Olesova N., Wpływ społeczeństwa obywatelskiego na jakość życia osób z niepetnosprawnością intelektualna, [w:] Wpływ ruchu rodziców osób z niepetnosprawnościq intelektualną na rozwój nauki i życie społeczne. Raport z badań, Warszawa 2014.

Ostrowska A., Sikorska J., Gąciarz B., Osoby niepetnosprawne w Polsce w latach dziewięćdziesiątych, Wydawnictwo Instytutu Spraw Publicznych, Warszawa 2001.

Rucht D., Themes, logics, and arenas of social movements: a structural approach, [w:] International Social Movement Research, t. 1, red. L. Kriesberg, JAI Press, Syracuse.

Sokołowska M., Ostrowska A., Socjologia kalectwa i rehabilitacji, Ossolineum, Warszawa 1976.

Sztompka P., Socjologia. Analiza społeczeństwa, Wydawnictwo „Znak”, Kraków 2005.

Sztompka P., Socjologia zmian społecznych, Wydawnictwo „Znak”, Kraków 2010.

Toënnies F., Wspólnota i stowarzyszenie, Wydawnictwo Naukowe PWN, Warszawa 1988.

Touraine A., The self-production of Society, University of Chicago Press, Chicago 1977.

Touraine A., The Voice and the Eye, Cambridge University Press, Cambridge 1981.

Wittel A., Towards a network society, "Theory, Culture and Society” 2001, t. 18, nr 6. 